\title{
Diagnosing Asthma Expert System with Case Base Reasoning Methods
}

\author{
Margaritha M. Kune ${ }^{1}$, Erwin Panggabean ${ }^{2}$ \\ ${ }^{1.2}$ Informatics Engineering Study Program, STMIK Pelita Nusantara, J1. Iskandar Muda No. 1 \\ Medan, North Sumatra, Indonesia 20154 \\ E-mail: ryamargreth91@gmail.com
}

\begin{abstract}
Asthma is a disease that is Often found in society, especially in the elderly. Asthma is a longterm chronic disease, if left to be fatal and can cause death. Limited access and costs, to patient health information, it is difficult, to know how much influence the disease. So to find out it needs to be built a simple application that can help and Facilitate the community. The purpose of this application is to identify asama disease in older people with 15 symptoms. For the development of expert systems, Several stages are needed items, namely: Analysis and Design of the data collection. This expert system application complies with asthma used by experts and users.
\end{abstract}

Keywords: Expert System, Asthma, Diagnosis, Case Reasoning

\section{Introduction}

The use of technology has become the common needs of the present era. In the use of a technology is also used to determine and solve a problem in various bidanag. One of them in the health sector, therefore it is very necessary to have an application that can give you information like an expert. Diera present any thing can be done with the help of technology. Such as building an application to diagnose a disease for example, methods Case Base Reasoning (CBR). CBR method is a method used to solve a problem by using previous experience in order to solve a new problem with regard to aspects of the similarities between the completion of some previous issues as well as the construction of a database system to store a revision to a solution of new problems. Casebased reasoning (CBR) to help in giving some relevant reasons to support the decision. Case-based reasoning applied in various ways. For example, in the field of law, Case-based reasoning can be used in taking a decision on a case. Examples diagnose diseases (asthma) asthma .Penyakit derived word "asthma" from the Greek word meaning "hard to breathe". Asthma is a chronic (long lasting) is characterized by shortness of breath accompanied by the sound ngik-ngik (wheezing) or cough parsisten where the severity of each person is different. At the time of the attack that happened was the narrowing of the airway us a result of the contraction of bronchial causes air to be difficult and out of the lungs. Common symptoms of asthma include wheezing, chest tightness, and shortness of breath. Lung disease and prnapasan tract disease attack rate is quite extensive and can affect anyone, regardless of age. In everyday life met many diseases such as asthma, tuberculosis, cough and fever in people's lives. Asthma is a disease that can not be underestimated, because if allowed to continue could result in other emerging diseases and also commonly cause death if not treated immediately. Asthma can be caused by respiratory disorders and lifestyle that is not appropriate, environmental influences, diet, and also infection of the throat caused by bacteria and viruses. Asthma in public life is often impaired in breathing that can make people with difficulty in performing certain jobs.

\section{Theory}

\subsection{Definition of expert systems}

According to Azmi and Verdi Zulfian Yasin, expert systems were developed in the mid tahaun (1960) this system appears first is Pursepose General Problem Solver (GPPS) developed by Newel and Simon. An expert system is a system that adopts the skill of an expert in a particular field into the system or a computer program is presented with a display that can be used user who is not an expert, so that system users can make a decision or set policy like an expert.

\subsection{Basic Concepts of Expert Systems}

Describe the basic concepts of the expert system within the system concept that expert users submit information to the expert system which further the facts and the information will be saved to the knowledgebase and processed by an inference engine so that the system can provide feedback to the user in the form of expertise and answers based on knowledge conveyed earlier. Andriani (2014). Examples of expert systems in everyday life in various fields, among others: 

1) field of Medicine
2) industry
3) psychology
4) managerial
5) Economics
6) Field of education
7) Legal Affairs and Security
8) Nature Exploration field
9) Agriculture Sector

\section{Research methods}

\subsection{Data collection}

Methods of data collection is a process conducted by researchers to collect data. Data collection was done to assist researchers in collecting the data data-functioning in the process of summing up the results of research, The method by the author in the data collection are interviews that the authors conducted a $\mathrm{Q}$ with a specialist in order to determine the existing problems at the clinic responsible through face to face.

\subsection{Data analysis}

The data analysis technique aims to decipher and solve problems based on the data obtained. The authors analyzed data is data cataract eye disease symptoms and types of cataract eye disease.

\subsection{Data processing}

Data processing is a very important part of the scientific method, due to the processing of data, it can be given meaning and useful in solving research problems. The raw data that have been collected have to be broken into groups, held categorization, so that such data has meaning to address the problem and useful to test the hypothesis or research question.

\section{4 design}

The planning stage is a stage that aims to design an expert system that can be used to simplify the user know the type of eye cataracts and cataract eye symptoms. Applications created using PHP programming language, so that more accurate results with methods Certainty Factor.

\subsection{Implementation}

In this section contains the conclusion of the data processing and discussion obtained from research.

\section{Results and Discussion}

1.gejala cataract eye used to the questions that will come out at the time of the consultation.

Table 3.

type Asthma

\begin{tabular}{lll}
\hline Code types of asthma & name of disease & \\
\hline P01 & Allergy & \\
P02 & Sports & \\
P03 & Cough & \\
P04 & specific job & \\
P05 & Evening \\
P06 & Drug \\
P07 & Other conditions that \\
& trigger \\
\hline
\end{tabular}

Table 4.

The level of disease cases

\begin{tabular}{lc}
\hline \multicolumn{1}{c}{ The level of disease cases } & Value \\
\hline Light & 0 \\
I & 0.40 \\
Chronic & 0.80 \\
Critical & 1 \\
\hline
\end{tabular}


Table 5.

Prevention

\begin{tabular}{|c|c|c|c|}
\hline No. & Diseases code & Disease name & Prevention \\
\hline 1 & $\mathrm{P} 01$ & Allergy & Avoid, dust, mold mites, cigarette smoke \\
\hline 2 & $\mathrm{P} 02$ & Sports & $\begin{array}{l}\text { Use of the inhaler before exercise but } \\
\text { exercise "not" cause asthma }\end{array}$ \\
\hline 3 & P03 & Cough & $\begin{array}{l}\text { Immediately do check to dokterspesialis } \\
\text { lungs to see how your lungs }\end{array}$ \\
\hline 4 & P04 & specific job & $\begin{array}{l}\text { Avoiding exposure to air pollution } \\
\text { chemicals smoke machine, smoke }\end{array}$ \\
\hline 5 & $\mathrm{P} 05$ & Evening & $\begin{array}{l}\text { Always provide asthma medication and } \\
\text { immediately consult a doctor specialists }\end{array}$ \\
\hline 6 & P06 & Drug & $\begin{array}{l}\text { Avoid medicines that are hard, and } \\
\text { consult a doctor before taking any } \\
\text { medication }\end{array}$ \\
\hline 7 & P07 & $\begin{array}{l}\text { Other conditions that } \\
\text { trigger }\end{array}$ & Consult a doctor \\
\hline
\end{tabular}

\section{Sample case}

$\begin{array}{ll}\text { Disease P01 = "Allergy Asthma" } & \begin{array}{l}\text { weight }=5 \\ \text { G01 (colds) }\end{array} \\ \text { G02 (sneezing nonstop) } & \text { weighting }=3 \\ \text { G } 03 \text { (scratchy throat) } & \text { weighting }=3 \\ \text { G10 (irritation) } & \text { weight }=1 \\ \text { G11 (watery eyes) } & \text { weight }=1\end{array}$

Completion is:

$(1 * 5)+(1 * 3)+(1 * 3)+(1 * 1) /\{5+3+3+5+5+5+5+3+1+1+1+3+3+3+5)(1 * 1) /\{3+3+$ $5+5+5+5+5+3+1+1+1+3+3+3+5)=13 / 51=0: 25$

Then from the calculation of these symptoms, including diseases "Allergy Asthma" Asthma and allergies are included in the category of "mild"

\section{Conclusion}

From the formulation of the problem until the completion of the program can be summarized as follows:

a. Design and manufacture of systems in asthma to be a solution for people to be able to resolve some of the problems that the limitations of time and energy can be replaced with a system that counts the keshatan convenience for people in the field without any obstacles.

b. Memebrikan expert system and alternative solutions to build an expert system diagnosis of asthma accurate and fast which aims to facilitate a doctor and patient. One way to build a simple diagnosea expert system, the researchers develop now required in a system with their understanding and learning it is a simple application will be created. And the system will be used to diagnose symptoms that exist so that the system will quickly figure out the illness. And this system will be displayed on the application software expert system.

\section{Reference}

[1] Samsudin,Usman,selviana “Aplikasi Sistem Pakar Diagnosa Penyakit Pernapasan Menggunakan Metode CBR "(Case Base Reasoning )

[2] Zulfian Azmi,Verdi Yasin" Pengantar Sistem Pakar dan Metode (2017)

[3] Anik Andriani, " Pemograman sistem pakar", Yogyakarta: Mediakom 2016

[4] Heru,Sundaru"Asma"Universitas Indonesia Jakarta (2018)

[5] TiaraEka Putri,Desi Andreswari,\& Rusdi Efendi (2016). "Implementasi Metode CBR (Case Base Reasoning Dalam Pemilihan Terhadap Hama Padi Sawah Menggunkan Algoritma K-Neares Neighbor(KKN) (studi kasus Kabupaten Seluma) Jurnal Rekrusif

[6] Agung Septian Gumelar,Mochammad Chandra Saputa \& Niken Hendarakusuma Wardani"Analisa Kebutuhan Dan Perancangan Sistem Informasi Produksi Dinas Kesehanatan Hewan Kabupaten Malang Berbasis Teknologi Service Orinted Architecture

[7] Arno Reza Pahlawan, Setyawanwibisono"Implementasi Case Base Reasoning Untuk Sistem Diagnosis Hama dan Penyakit Tanaman Cabe Merah Menggunakan Algoritma Similaritas Neyman". Universitas Stikubank (2017) 